\title{
Eesti kaerajaanid ja tantsutüpoloogia ${ }^{1}$
}

Peeter Pomozi

Teesid: Ammusest ajast on mõeldud, et keelte dialektoloogia ja tüpoloogia analoogia põhjal on võimalik uurida ka rahvatantse. Ungari tantsuteadlased György Martin ja Ernö Pesovár katsusid mitmes ungari tantsudialektidest ja motiividest koostatud uurimuses ja monograafias (nt Martin \& Pesovár 1960, 1964; Martin 1995, täiendatud, postuumne trükk) teoreetiliselt kokku võtta, kuidas võiks kasutada tantsuteaduses etnomusikoloogia ja keeleteaduse uurimismeetodeid. Artiklis vaatan lähemalt ka seni rakendatud nö strukturaalset lähenemisviisi ning tüpoloogilise uurimismeetodi iseloomulikke jooni tantsuteaduses. Seega lähtub mu artikkel eeldusest, et teatud tantsudel ja tantsutüüpidel on oma varieeruvuseski suhteliselt kindel ja kaardistatav morfoloogia (tantsumotiivid) ning süntaks (struktuuri suuremad üksused, eesti tantsuterminoloogias mh tuurid ja tuuride osad) ning sel moel saab analüüsida Põhja-Euroopas levinud kontratantse ja uuemaid paaristantse.

Üksikasjalikumalt vaatlen uurimuse rakenduslikus osas eesti kaerajaane. Kaerajaan on tänapäeval Eestimaal üks tuntuimaid rahvatantse, millest on ka trükis ilmunud 17 varianti ja rohkesti lühiteateid Kristjan Toropi raamatus Kontratantsud (Torop 1995: 162-180). Ka soveldatud kujul, kümnetuurilise tantsuna nägi Kaerajaan ${ }^{2}$ ilmavalgust väga varakult: juba Anna Raudkatsi 1926. aasta raamatus Eesti rahvatantsud. Käesolev uurimus lähtub Toropi korpusest. Eesmärgiks on näidata kaerajaanide ja nendega motiivivara poolest sarnaste kontratantsude kaudu seda, kuidas on (ka) võimalik tantsutüüpe analüüsida ja tantsumotiive kaardistada.

Märksõnad: kaerajaanid, tantsumotiivid, tantsutüübid, tantsutüpoloogia

\section{Keeleteadus ja tantsuteadus: analoogsete uurimismeetodite küsimus}

\section{Hiiu neidude-naiste vööl rippuvast arsenalist}

Folkloristid on ammu märganud, et teatud keeleliste ja folkloorsete nähtuste territoriaalne levik võib kattuda, teisisõnu võivad omavahel sarnaneda ühe suurema ala folkloorsed, etnograafilised ja keelelised isoglossid. Nii kattusid 
varem võrdlemisi täpselt Lääne- ja Ida-Soome murdepiir ning kõva leiva (rõngasleiva, näkileiva) ja pehme leiva levikupiir. Teatud inimrühma keeleline diferentseerumine võib alati kaasa tuua ka kultuurilise eristumise. Ja vastupidi. Keelelist eristumist võib põhjustada mõne teise äsja naabrusse elama asunud rahva(osa) ihaldatud, prestiižikaks peetud või lihtsalt domineerima hakkav kultuur. Ka valitseval usul on määrav roll, seegi võib põhjustada või konserveerida kombestikulisi erinevusi, mõtleme kas või setu keele ja kultuuri eripärale Eesti mandrimaal. Seega on selge, et tantsuteadlaste tee oli üsna sirge ideeni: kui tantsufolklooris on murretega sarnaseid nähtusi, võib tantsuuurimine rakendada üht-teist keeleteaduse uurimismeetoditest.

Looduslikul viisil (geograafiliselt) isoleeritud rühmadel on pärimuslikudkeelelised erinevused ja kattuvused sageli veelgi silmatorkavamad. Ühelt Eesti äärealalt, hiidlastelt võtangi tantsufolkloorse-etnograafilise näite, et jääda artikli kitsama teema juurde. Hiiumaa tuntud koreograaf Hele-Mare Kõmmus arvab, et Hiiu valsi unikaalne tantsuvõte, ${ }^{3}$ kus uuema kihistu paaristantsudest kardinaalselt erinevalt on poisi ja tüdruku puusad üksteisest kaugel, kujunes ehk välja usulahkude mõjul, ${ }^{4}$ mis muutusid 19. sajandiks hiidlaste elus määravaks, ja nemad hakkasid kohalike tantsurõõme rangelt kärpima, takistamaks igasugust "liiderdamist" ja "põrgulõbu". ${ }^{5}$ Selle ideoloogilist peegeldust näeme ka salmis "hüpake ja karake, küll te põrgus olete".

Teine (mulle südamelähedane) seletusvõimalus: võte tekkis kohaliku naisterahva kaasas kantava "arsenali" pärast, mis kuulus nii igapäevaste tegemiste kui ka pühapäevase kirikurõivastuse juurde. Hiiumaa naise vööl rippusid rõhtude kõrval nõelakoda ja korralik suur nuga, mis asus rippuvas tupes. Küsimus, kas viimane seletus oma tõepärasusele vaatamata tegelikkusele vastab, on lahtine, sest me kahjuks ei tea, kas tüdrukud jätsid tantsima minnes need "aarded" vööle rippuma. ${ }^{6}$ Kui jätsid, siis pididki paariliste puusad üksteisest eemal olema, sest Hiiu valsis pööreldakse ${ }^{7}$ kiiresti, ja sel puhul oleks rippuvad esemed kujutanud endast tantsijaile ohtu või oleksid vähemasti neid seganud.

Nii palju ainelise rahvakultuuri ja folkloori võimalikest seostest, nüüd aga vaatame lähemalt metoodilisi paralleele, et jõuda tantsutüpoloogia mõisteni.

\section{Motiivid - struktuur- tüüp: tantsumotiividest tantsutüpoloogiani}

Tantsutüpoloogiat mainitakse mitmel pool maailma rahvatantsu-uurimustes, ka Fennoskandias, ent see ei tähenda sageli rohkemat kui teatud tantsutüüpide ja alatüüpide liigendamiskatset, ${ }^{8}$ st sageli polegi tegu keeletüpoloogiaga analoogse uurimismeetodiga, vaid lihtsalt uurimisobjektide klassifitseerimi- 
sega. Tampere ja Põldmäe jagasid rahvatantsud tüüpidesse latentselt. Valimik sisaldab ka lühikest "tüpoloogilist ülevaadet" ringtantsudest paaristantsudeni (Tampere \& Põldmäe 1938). Strukturaalse analüüsi teerajajaks oleks võinud Eestis tõusta Kristjan Torop. Tema kontratantsuraamatu sissejuhatusest leiame strukturaalse analüüsi alget (Torop 1995: 17-28). Ta liigendas publitseeritud kontratantsude motiivid alarühmadesse, kuid tema töö jäi kahjuks varase surma tõttu pooleli.

Ungari tantsuteaduses hakati viljelema tantsude tõelist strukturaalset analüüsi juba 1950ndail aastail ning sealse rahvatantsuteaduse kahe suurkuju György Martini ja Ernő Pesovári silmis tähendas tantsu(tüüpi)de uurimine süvaanalüüsi kolmes suures valdkonnas: sisu, muusika ja vorm. Varasematest aegadest tuntud tantsudialektoloogilis-ajalooline lähenemine täieneb nende elutöös muuhulgas ka detailse vormianalüüsiga, kusjuures vormianalüüsi eri aladeks on veel koreograafiline ja strukturaalne analüüs (vt Martin \& Pesovár 1960: 211-212).

Martin ja Pesovár lähtuvad oma põhjapanevas uurimuses sellest, et keel ja tants on vormiliselt analoogsed, ${ }^{9}$ ja sellepärast on tantsu-uurijal võimalik rakendada keeleteadusest laenatud uurimismeetodeid.

Eriti palju analoogiaid, lähtekohti, metodoloogilisi kogemusi saame etnomusikoloogiast ja keeleteadusest. Mõlemal teadusalal on kindlad metodoloogilised alused, ja mõlemad pakkuvad analoogiaid oma uurimusobjekti olemuse sarnasuse poolest. Seega muusika-ja keeleteaduse terminoloogia on heaks aluseks tantsuteadusele, loomulikult tantsude jaoks kohandatuna [Különösen sok analógiát, indítékot és módszertani tapasztalatot szolgáltatott munkánkhoz a népzenetudomány, valamint a nyelvtudomány. Ezt különösen az tette lehetövé, hogy mindkét tudománynak módszeresen kidolgozott a formatana és mindkét tudományág tárgya természeténél fogva szolgáltat analógiákat a tánchoz. A zene- és nyelvtudományban használt terminológiák éppen ezért önként kínálkoztak felhasználásra, természetesen táncra alkalmazott módosított formában] (Martin \& Pesovár 1960: 214).

Etnomusikoloogiast mainivad autorid Ilmari Krohni ${ }^{\mathbf{1 0}}$ välja töötatud ja hiljem Béla Bartóki modifitseeritud ja edasi arendatud rahvalaulude liigendamissüsteemi (Bartók 1924). ${ }^{11}$ Keeleteaduslikku analoogiat vaatame lähemalt allpool. Martin ja Pesovár nentisid, et vormianalüüsi nimel tegelesid varasemad ungari soost uurijad rohkem koreograafilist laadi vaatlustega, st analüüsiti liigutuste rütmikat ja plastikat, kuid tegeliku uurimuseesmärgini, tantsu olemusest arusaamiseni on võimatu jõuda ilma strukturaalse analüüsita: 
Kujundamaks pilti kogu tantsust ja selle orgaanilisest ülesehitusest peame terviku koostisosadeks lahkama. Tantsu eri väiksemate ja suuremate osade kindlaks mä̈̈ramine ja õige segmenteerimine ongi tantsu strukturaalse analü̈̈si eeltingimuseks. [Az egész összetevőkre bontása az alapja annak, hogy képet alkothassunk az egész táncról, és annak organikus felépítéséről. Éppen ezért a szerkezeti elemzés előfeltételének tartjuk a tánc részeinek, kisebb-nagyobb egységeinek helyes felismerését, tagolását, melyekből a tánc szerkezete felépül] (Martin \& Pesovár 1960: 214).

Motiiv on nende arvates tantsu väikseim orgaaniline liikumisüksus, millel on kindel rütmika ja kinnine liikumisskeem. ${ }^{12}$ Toropi definitsioon on lahtisem, kuid eeltsiteerituga kooskõlastatav:

Sõnaga motiiv olen tähistanud tantsudes olevaid ühetaolisi tegevusi, olenemata sellest, mitme takti jooksul või missuguste tantsusammudega seda tegevust sooritatakse (Torop 1995: 18).

Koreograafilis-kineetilises lähenemiseski on motiiv omaette kunstiline tervik, käsitletava aine üks element, täpsemalt aga jooniselt ja rütmilt kindel inimkeha liigutus. Koreograafiline motiiv on koreograafilise teksti algmaterjaliks. Kui panna tantsu liikumisüksusi suurusjärjekorda, saame strukturaalse analüüsi jaoks struktuuritasandid:

liigutuselement $>$ motiiviosa $>$ motiiv $>$ motiivirida $>$ $>$ tantsuosa $>$ tantsutuur ${ }^{13}$

Neist struktuuritasandeist lähtuvalt võib tantse uurida nagu verbaalse koodi lauseid ja sõnavorme kuni üksikhäälikuteni. Sõnavormid on keele ehituskivid, mis võivad koosneda paljast sõnatüvest, aga viimasele võivad eelneda eesliited ja/või järgneda järelliited ja/või lõpud. Keele morfoloogia on nende morfeemide ja nende kombinatsioonide õpetus ning sõnatüvi ja liited on väiksemateks orgaanilisteks üksusteks. Tantsumotiiv on umbes keele morfeemi suurusega strukturaalne osa, olles tantsu väikseim orgaaniline üksus. Keeltega tegelejana lisan, et motiividega päris sarnaseks pean täpsemalt nn vabu morfeeme, ${ }^{14}$ ja neid, mis ei saa esineda lauses iseseisvalt, nt erinevad afiksid, eesja järelliited, pigem motiiviosadeks. Selle oletamist toetab ka seik, et liigutuselement (motiiviosad koosnevad just neist) arvatakse olevat analoogne häälikuga. Kui mõelda veel sellele, et koreograafilise teksti algmaterjaliks, st kõige pisemaks koreograafiliselt tõlgendatavaks koostisosaks on just nimelt mo- 
tiiv, siis on iseseisva tähenduseta motiiviosa pigem nagu iseseisva tähenduseta morfeemid keeles, st afiksid, millel on üksnes grammatiline tähendus. Samas on ilmne, et ei maksagi otsida verbaalse ja mitteverbaalse koodi struktuuritasandite täielikku kattuvust, ja seega jääb motiiv veidi umbmääraselt vaba morfeemi ja sõnavormi piirimaile.

Tantsumotiividki võivad olla liht- või liitmotiivid, et mitte rääkida koondmotiividest. Martin ja Pesovár andsid väga täpse iseloomustuse motiividest ja rakendasid ungari eri tüübi rahvatantsudes väga tulemusrikkalt oma motiiviõpet (vrd nt Martin \& Pesovár 1964).

Siinkohal meenutagem et kõik siiamaani öeldu kehtib kõige tõenäolisemalt Euroopa tantsuajaloolises ja kultuuriloolises kontekstis, aga see ei tähenda veel kuigi palju meie teoreetiliste märkuste universaalsuse kohta. Nende kehtivuse eelduseks on just nimelt kultuuriruumi omapära, see kuidas me siin Euroopas erinevatest tantsudest aru saame, olgugi et nad on pärit erinevaist tantsuajaloolistest kihistustest. Maailma eri kultuurides võivad olla verbaalsete (nt keel) ja mitteverbaalsete koodide ( $n$ t tants) vahel hoopis teised suhted, mis ei võimalda tingimata teha samu struktuurilisi järeldusi ja rakendada automaatselt säärast analoogiat. Küsimus ongi selles, millised tantsud on liigitatavad ja segmenteeritavad nagu keelelised üksused. Fennoskandias laialt levinud kontratantsud ${ }^{15}$ on kindlalt sellised. Tõsi küll, et Eesti talupoegade juures ei saavutanud nad erilist populaarsust, seega on need struktuuriliselt lihtsamad, kui nende Soome, Karjala või Läti vasted. Kuid just oma lihtsuse tõttu sobivad hästi käesoleva artikli näitematerjaliks.

Lihtsatest ühetuurilistest rahvatantsudest leiame sageli vaid kaks motiivi. Kadrillide perre kuuluvast siisikust (Torop 1995: 115) nt ainult tervitamise ${ }^{\mathbf{1 6}}$ ja käärhüpped. Lihtsamast Jämaja kuo tu tetsust (Torop 1995: 116) jälle ainult paariliste kohavahetuse ning põimumisega pöörlemise käevangus, kuid eesti kuo tu tetsul on variante, kus tants lõpetatakse kontratantsudele hilisemal ajal iseloomulikult ringjoonel paaristantsuga, seega muutub tantsu struktuur veidi põnevamaks. Soome kadrillide perest üks lihtsaimaid on sappu Viipurista (Tanhuvakka 1977: 256), milles on peale kuo tu tetsu põhimotiive ka ringjoonel kõndimine ja ringjoonel kätlemine. Veelgi keerukamais Soome ja Karjala kadrillidest leiame hulk teisi motiive, nt sappu Säkkijärveltä17 (Tanhuvakka 1977: 253-255) motiivivara juurde kuulub veel oma paarilisega pöörlemine, ka naised lähevad võõraste meestega pöörlema (poikien ja tyttöjen haalo), käeristis käimine (poikien ja tyttöjen risti) nagu eesti kaerajaanide B-osas, ning lõpetuseks ühendavad poisid ruusust käed mõnes tugevas võttes, tõstavad tüdrukud oma kätte peale ja kõnnivad niiviisi tantsu viimases B-osas päri- ja vastupäeva ringi. Nende tantsude motiivid on väga sarnased, isegi motiivide järje- 
korras on väga palju kokkulangevusi, järelikult on väga sarnane ka nende tantsude struktuur, kuid ülilihtsast jõuame siiski võrdlemisi keeruliseni. Grammatikast võetud metafooriga väljendades lihtlausest poeetilise põimlauseni.

Struktuuri - ja nt teatud tantsude struktuurilist sarnasust - kirjeldasid Martin ja Pesovár hästi võrreldaval, kompaktsel ja abstraktsel kujul (vt Martin \& Pesovár 1964). Ma nimetaksin neid tantsuvalemiteks. Kuo tu tetsu kohta oleks esimene samm tantsuvalemi tegemiseks selline:

$$
\mathrm{A}_{1+2}(\mathrm{Ia}+\mathrm{Ib})\left|\mathrm{B}_{1+2}(4 \mathrm{xIIa})\right| \mid
$$

Suurte tähtedega märgitakse muusikapala põhiosad, rooma numbritega motiivid, väikeste tähtedega motiivivariandid, korrutamine tähendab siin motiivi neljakordset kordamist. Ühekordne joon (tsesuur) tähendab siinkohal motiivi kindlat lõppu (vahepausi), kaksikjoon aga tantsu lõppu. Tegelikud tantsuvalemid näevad välja märksa abstraktsemad ja enamasti on nad keerulisedki, sest nad informeerivad ka liigutuste intensiivsusest ja liikumistasandeist, võimalikest kordamisperioodidest, motiivide üleminekust ühest tantsuosast teisesse, juhul kui selline esineb jms. ${ }^{18}$ Seega on siin antud kuo tu tetsu pisivalem üksnes luukere, millele tuleks liha peale kasvatada. Martini ja Pesovári tantsustruktuuri kirjeldamissüsteemist ei hakka siinkohal siiski rääkima, esiteks ei mahu selle seletamine käesoleva uurimuse raamidesse, teiseks olen veendunud, et mõnel määral tuleb see eesti tantsude analüüsimiseks ümber töötada.

\section{Vahemärkus murdegeograafiast ja tantsukaartidest}

Ka tantsudialektoloogia laenas oma põhimeetodid keeleteaduselt, lähemalt murdegeograafiast. G. Martin ${ }^{19}$ tõmbaski rohkeid paralleele kahe uurimusvaldkonna vahele:

peame rõhutama, et tantsudialektide piirid on harva selged, piiride asemel võime rääkida pigem järk-järgulisest üleminekust ühelt alalt teisele [---] teatud nähtused kontsentreeruvad kimpudesse, ja nende põhjal on võimalik määrata erinevate dialektide keskseid omadusi, [---] üheainsa nähtuse territoriaalse leviku piirjoon ei anna tugipunkte dialektuaalse piiri tõmbamiseks, selle tegemiseks tuleb uurida paljusid relevantseid nähtusi, [---] tantsugeograafilise töö juures ei tohi unustada ka nähtuste levikut ajas (Martin 1995: 21-22). ${ }^{20}$ 
Martin ei kasuta kaardistamistöö käigus järjekindlalt murdegeograafia sõnavara, kuid ka tema kaartidel on tegu isoglosside ja kimpudega (parmastega).

Tantsukaardid on olnud enesemõistetavalt sümbolkaardid, sest tants on mitteverbalne kultuurinähtus, ja tantsumotiivide kaardistamine, üldse ka motiivide eristamine, on abstraktsiooni tulemus.

\section{Kaerajaanid trükis}

Kaerajaan ilmus soveldatud kujul kümnetuurilise tantsuna väga varakult, juba Raudkatsi 1926. aasta raamatus Eesti rahvatantsud. Varasemad andmed kaerajaanide kohta ja varasemad esitamised ei puutu praegu teemasse. Raudkatsi kogumikust sai alguse Kaerajaani lavakarjäär. Märksa hiljem nägid päevavalgust esimesed folkloristide kaerajaani-avaldamised ja kommentaarid, siin pean silmas kõigepealt Tampere postuumset raamatut ning Toropi kontratantse (Tampere 1975: 66-70, Torop 1995: 162-180).

Kristjan Toropi raamatus Kontratantsud esineb 17 tantsukirjeldust ja rohkesti lühiteateid, mida ta luges kaerajaani-tüüpi kontratantsude hulka. Kuid avaldatud variantidest leidub ka üleminekutüüpe mõne teise sarnase kontratantsutüübi nt kupparimuori ja "ehtsate kaerajaanide" vahel. Mõistagi esineb ka vastupidist, oli võimalik ja oligi tantsitud nii kupparimuorilikku kaerajaani kui ka kaerajaanilikku kupparimuorit. Aga sellest vt lähemalt punkt kahes

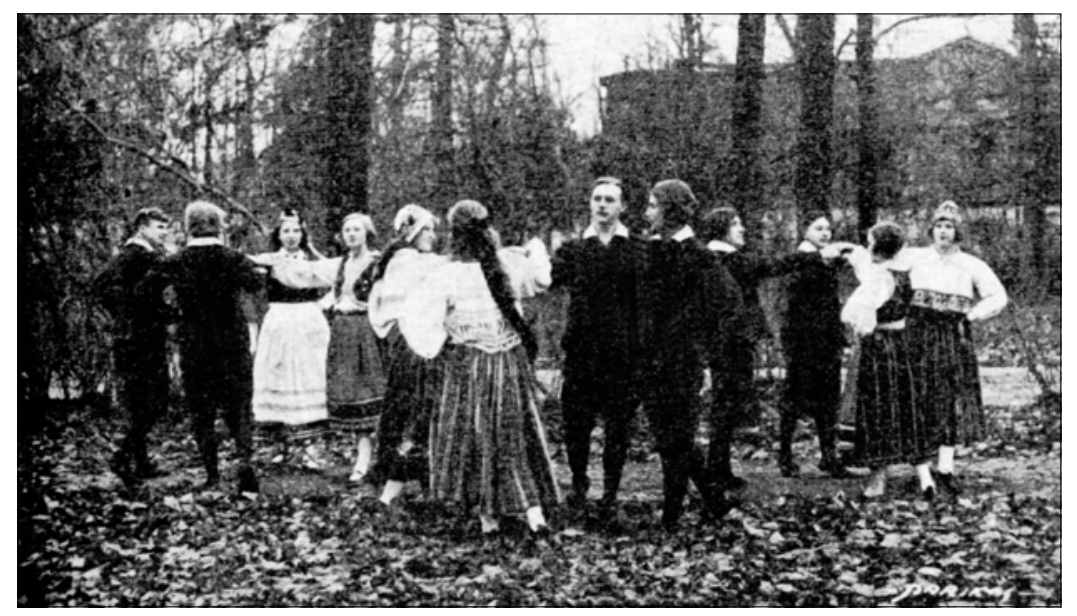

Joonis 1. Kaerajaani esimese tuuri B osa Raudkatsi raamatus: pöörlemine päripäeva. 
järgmises alajaotuses. Kaerajaani võtmemotiiv (Toropil leitmotiiv) on aeglaste ja kiirete käärhüpete vaheldumine tantsu A-osas kadrillidele iseloomulikus nelinurkasendis (vrd Torop 1995: 25-27). Kuid tüüpmotiivist saab üksnes folkloorse tantsu tuuma, mitte rohkem, terve tantsu valemit ei saa ainsa motiivi põhjal kirjeldada. Pealegi on kontratantsude alaliigid üksteisele nii sarnased, et neid on huvitav vaadelda motiivilises kontekstis, mitte isoleeritult. Viimane oleks uurimismeetodina võrreldav sellega, nagu tahetaks teatud keele deklinatsioonist aru saada mõne käänatud sõna abil ilma süsteemiga tutvumata.

ERAs hoitud folkloorsete eesti kontratantsude kirjeldused on lihtsad, tantsud sageli ühetuurilised, mis peegeldub ka Toropi 1995. aasta raamatus. Tantsude fragmentaarsuse põhjuseks, mille omaette sümboliks on ka lühiteadete ülekaal avaldatud materjalis, on mõistagi see, et kogumishetkel polnud enam antud kontratantsutüüp antud kohtades ja kihtides elav, informandid olid valdavalt eakad naised, kes käisid kepsutamas nooruses. Teiseks põhjuseks on siiski ka see, et Torop kõrgelt haritud filoloogina redigeeris ja kogus ise võimalikult täpselt võimalikult palju relevantset materjali. ${ }^{21}$ Siiski mainib ta oma kontratantsuraamatus, et palju fragmente jättis ikkagi trükki antud korpusest välja.

Kas lihtsa struktuuriga variandid on tekkinud keerulistest õukonnavormidest lihtsustumise teel või koosnevad mõned rikka motiivivaraga folkloorsed märkmed hoopiski mitmest tantsust, pole strukturaalseks analüüsiks esmatähtis, see küsimus kuulub pigem ajaloolis-võrdlevate uurimuste valdkonda. Kuid viimase uurimussuuna lähtepunktiks on jälle tantsustruktuuri mitmekülgne analüüs võimalikult suure korpuse põhjal. Siin mainingi ühte ajaga seotud seika, millega tuleb arvestada ka strukturaalse lähenemise puhul. Tõekspidamised folkloorsete tantsude ajaloolisest arengust (minu silmis muutumisest) on paratamatult suhtelised, sest tantsud elasid ja elavad oma varieeruvuses. Muutused ajas pole enamjaolt puhtlineaarsed ega puhttsüklilised. Erinevate tantsutüüpide ja alatüüpide vahelised seosed meenutavad pigem keerulist võrgustikku kui lineaarsete ja/või tsükliliste protsesside summat. Täpselt nagu nt ballaadivariantide puhul. Ka Ullo Toomi 1982: 42-43 arvamust kaerajaani originaalsusest tuleb vaadata läbi selle prisma.

Puhtlineaarset arengut polegi peaaegu olemas. Märksa põnevam on tsüklilisuse küsimus. Lossi köögiuksest tagasi salongini on teinud teed ka mitu Ungari aladel levinud tantsu. ${ }^{22}$ Sama on juhtunud ka kirjanduses mitme folkloorset laadi Petőfi luuletusega 19. sajandil, rahvas hakkas neid hiljem tsiteerima rahvalauludena. Harva esinevat tsüklilisust võiks kujutada nt nii: 
Tsükli faasid:

1. Folkloriseerumine

2. Folkloorse tantsu

motiividega rahvuslik ballitants

3. Refolkloriseerumine

SELTSKONNATANTSUD,

KÕRGKLASSI MOETANTSUD ${ }^{23}$

RAHVATANTSUD

\section{Kristjan Toropi avaldatud kaerajaanidest ${ }^{24}$}

\section{Muusikast ja tantsijate arvust}

Kaerajaani laulu all tuntakse üldiselt 3. varianti ja selle variante (Aud) (Torop 1995: 164). Ka Läti kõige levinum Cūkas Grịkose meloodia on sellega väga sarnane. Var 1 (Se) ning var 17 (Urv) on pigem Kaaratsimmi laul laiemas mõttes, nt samas Toropi raamatus on kirja pandud ka Kolmõgeski kaarassimmide (Se) saatemuusikana (Torop 1995: 111).

Saatelaulu struktuur on analoogne tantsustruktuuriga. $(2 \mathrm{xA}+2 \mathrm{xB}$, viimane täpsemalt $\left.B+B^{\text {var }}\right)$. Selle järgi karati marsitempos, folkloorsete variantide puhul MM=110-128. Mõlemas osas kaks korda neli takti, seega põhijuhtumil ühes tuuris kokku 16 takti. Liikumisskeemidest selgub et ka tantsudes 7 (Urv) ja 8 (Kod) koosneb A ja B osa kaheksast taktist, kuigi Toropil puuduvad täpsemad andmed, informandid enam ei mäletanud hästi. Väike kahtlus ärkab pigem 10. tantsu (Puh) B-osas, kus käiakse lihtsalt kõnnisammudega ringi nagu Kupparimuoris. Iseasi, et tõenäoliselt mõlemas suunas 4 takti, aga informandi puudulikke mälestuste tõttu jääb asi seletamata.

Tõeliseks erandiks on minu arvates Kupparimuia, mille struktuuriks on selgelt A4+B8. Nime järgi arvas informant nähtavasti, et tegu on pigem teise tantsuga. Märgakem, et selle tantsu B osa on - vastavalt tantsu nimetusele, Kupparimuoridele omase motiiviga, nii et on raske otsustada, kas tegemist on Kaerajaaniliku Kupparimuia või Kupparimuoriliku Kaerajaaniga. Arvatavasti pidi selle üle mõtisklema ka Kristjan Torop, ${ }^{25}$ aga ta laskis ennast veenda käärhüpetest. Ka 12. variandi puhul (Phl) tekkib sarnane kõhklus, kuid seal nimetati tants Kaerajaaniks, ja Torop nõustus sellega.

Laulu tekstivariante siinkohal ei käsitleta. 


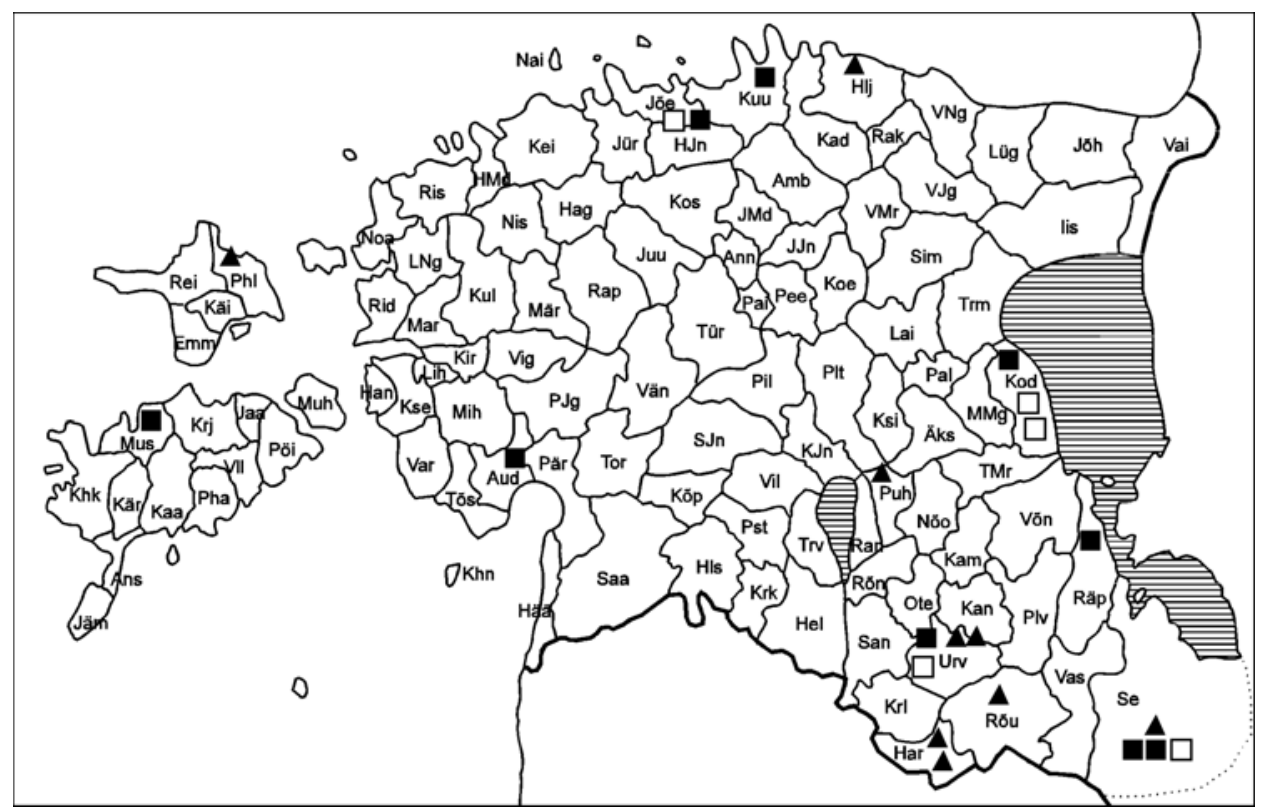

Joonis 2. Toropi avaldatud kaerajaanide kogumispunktid. - - kirjeldusest selgub et, tantsiti neljakäsi (kadrilliasendi esinemine). $\square$-kirjelduse põhjal on nelinurkasend rekonstrueeritav. $\mathbf{\Delta}$ - paaride arv on vaba, enamasti tantsisid naissoost paarid.

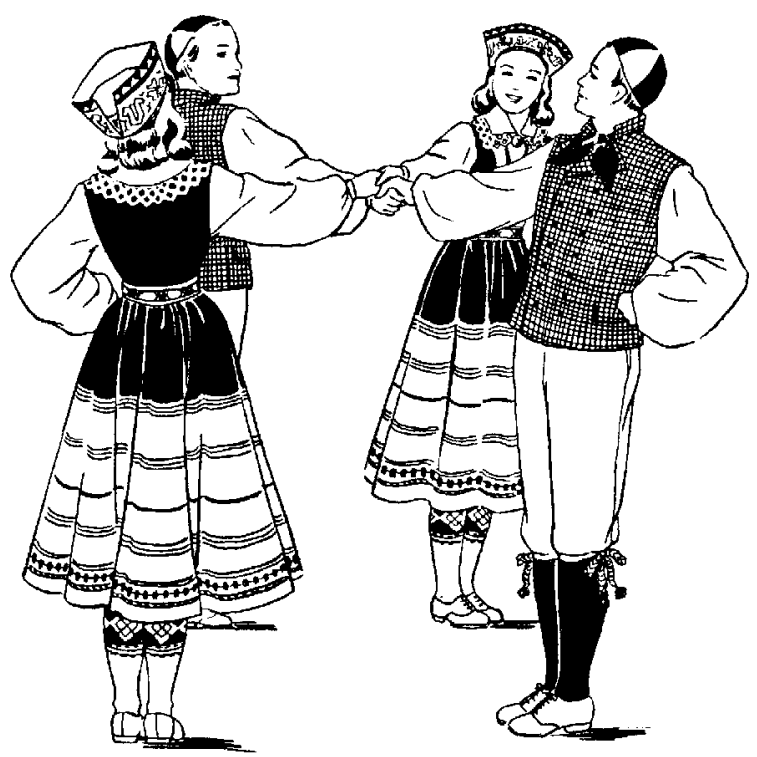

Joonis 3. Kaerajaani illustratsioon Toomi “piiblist”. Päripäeva pöörlemine. 
Tantsijate arvust ja kaerajaanide levikust annab kaart hea ülevaate. Tantsus osales üldjoontes 4 inimest (enamasti 2 paari), sagedasti kadrilli nelinurkasendis. Kuid näiteks variandis 9 (Har) on tantsijate arvuks vaba arv naispaare, samuti ka variantides 11-17. Siinkohal ei saa mainimata jätta, et var 9, 10 ja 12-17 kaaratsimmid on kõik kagunurga tantsud, kuid ka kagunurga andmebaasist leiame "õiget" kaerajaani, nimelt var 1 ja 2 (mõlemad Se). Naised tantsisid-mäletasid enamasti meestest paremini. Eespool oli juba juttu kupparimuia-nimelisest variandist $\mathrm{nr} 11(\mathrm{Hlj})$. Haljala variandi järgnevaks kupparimuorilikuks jooneks on paariliste vaba arv. Paarilised moodustavad siin sama moodi 2 rinnati viirgu, nagu nt tantsus Kupparimuori 12 (Kuu, Torop 1995: 92-93). Viimaste puhul otsustabki I tuuri A osa motiiv(ivara), kumb on kumb.

\subsection{Toropi avaldatud kaerajaanide motiivivara ja struktuur}

Järgmisel leheküljel olev tabel sobib hästi teatud tantsu((ala)tüübi) motiivivara esmaseks ülevaatamiseks, ja on küllaltki objektiivne. Loomulikult muutub kaerajaanide inventuur kohe põnevamaks, kui koostame tabeli ka sarnastest (kontra)tantsudest. Tabelis on Toropi avaldatud kaerajaanide täielik motiivivara, motiivid rasvase kirjaga, motiivivariandid tavalise kirjaga. Tabelist saab teavet ka iga tantsu konkreetse struktuuri kohta, A ja B osad on värvidega eristatud, et kohe tekiks hea ülevaade ja võrdlusvõimalus. Ka ebatavalised lahendused, erandid paistavad niimoodi kohe silma, nt Kodavere variant. Mõningaid järeldusi saab teha ilma suurema tantsukontekstita, so isoleeritult, ainult 17 kaerajaani struktuuri analüüsi abil.

Neist järeldustest tähtsamad:

1. Kaerajaanid olid vist valdavalt lihtsa ehitusega ühe- ja kahetuurilised tantsud, üsna kindlalt 16-taktilised. (See et Toropi kasutatud ERA-korpuses on nad ühetuurilised, ei tähenda tingimata enamat, kui seda, kuidas neid kogumishetkel mäletati. Sellest ei maksa teha ajas väga kaugele ulatuvaid järeldusi.)

2. Ei mingit Kaerajaani käärhüpeteta, ja käärhüpped kindlasti A osas. Nagu üleval öeldud, pidas Torop käärhüppeid kaerajaanide leitmotiiviks. Kodavere variant (8) on pigem erand, mis tekitab kahtlust. (Nt informant vahetas motiivide järjekorra ära või tekkis Kodaveres kaerajaani nö siirdevorm, sellest vt laiemalt eespool.)

3. Enamasti alustati käärhüppeid vasaku jalaga. (Kontratantsu traditsioon ja liikumisskeemid nõuavad enamasti mitte välis- või sisejalaga, vaid vasaku jalaga alustamist.) Ka pöörlemisega seotud iidne eesti reegel võib selles mängi- 


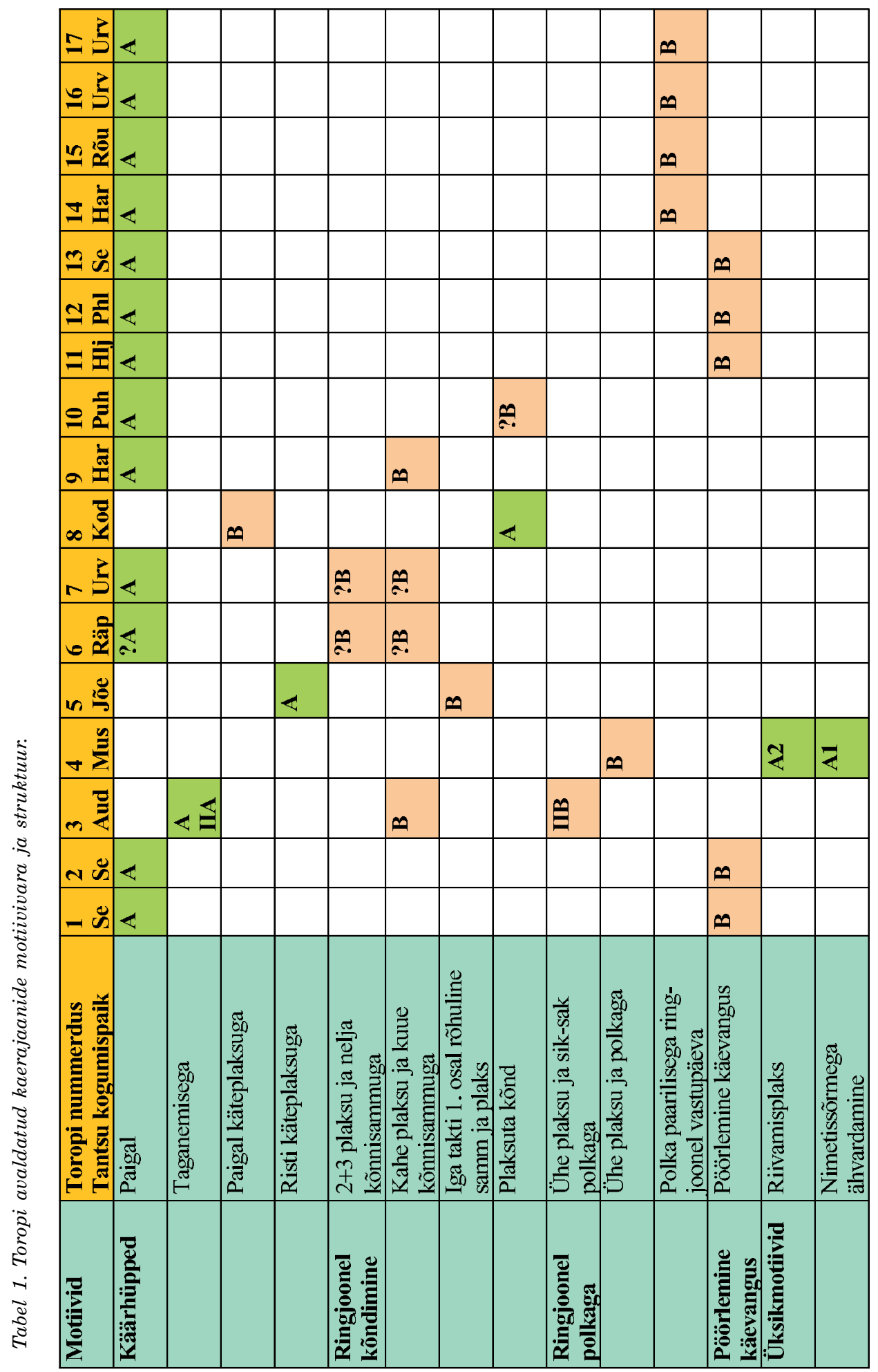


da teatud rolli; vanasti olevat kõigepealt kõnnitud/pööreldud päripäeva ja alles siis vastupäeva, kui tuli korrata. Päripäeva kõndimisel on suunajalaks vasak, muidu tuleks alustada ristsammuga, mis on lihtsatele eesti ringtantsude liikumisskeemidele üsna võõras. ${ }^{26}$

4. Ei ühtegi kindlat $2+3$ plaksuga nelja kõnnisammuga poolringi, sest see on Ullo Toomi seade, ${ }^{27}$ mis aga nii hästi välja tuli, et hakkas kohe folkloriseeruma. Tänapäeval on suurem osa rahvatantse tantsivatest eestlastest täiesti veendunud, et 2+3 plaksuga nelja kõnnusammuga poolring on kaerajaanide iidne motiiv. Raudkatsi Kaerajaanis oli muidugi ka kaks plaksu ja kuus sammu.

5. Tantsude 1-2 ja 11-13 põhjal tuleks tõmmata Haljala-Pühalepa-Setumaa(!) isogloss. Paarilisega käevangus pöörlemine on kupparimuoride üks peamotiive, kuid siin aitab pilk kontekstile ja tüüpide võrgustikule isoglossi lahti mõtestada, vt mõnede kontratantsude motiivivara kaarti lk 44. Kerkib muidugi küsimus, kumma tantsuga Setumaal siis tegemist on? Kas kupparimuoriliku kaerajaaniga või kaerajaaniliku kupparimuoriga või hoopis kolmanda tantsuga. Areaalsest vaatenurgast muidugi mitte kupparimuoriga. Kuid kui vaadata, mida nimetatakse milleks eesti kontratantsutraditsioonis, tunduvad erinevate tantsude piirid olevat väga suhtelised.

6. Hargla-Urvaste-Rõuge (var 14-17): silmapaistev ühtsus (küllap tungis üldine moevool B osas vanema motiivi kohale, vana tantsu värskendati).

7. Riivamisplaks tundub ebakindel, selle kohta on andmeid ainult ühelt informandilt. Üldse on riivamisplaks folkloorsetes tantsudes suhteliselt harva esinev liikumiselement. Seevastu on ristikäärhüpped levinud ka Lätis, Cūkas Grīḳoses, st selle kohta kogutud andmed on usaldatavad, kuigi nad on pärit Jõelähtmest.

8. Ringjoonel kõndimine esineb alati nelja tantsijaga variantides. Hea oleks öelda, et Kaerajaani vanem vorm oli ühetuuriline, A osas käärhüpetega, B osas plaksuga ringikõndimisega kahele paarile, ja päris vana sõõris kõndimise asemele tungis moevooluna paarispolka ringjoonel vastupäeva, ning kohati elasid paariviisi sooritatud, ringjoonel (pp-vp) liikuvad motiivid uue moevoolu kallaletungi üle. Võimalik on ka see, et üldse vahetati suurel ringil paljude tantsijatega kõndimine moeka paaristantsu vastu, mõelgem et kaerajaani minimalistlik kadrilliasend nelja osavõtjaga ei ole kõige mõistlikum lähteasend suure ringi peal polkatamiseks. (Kuo tu tetsus on neli paari, nelja paariga sai juba hästi ringil polkatatud, kolmepuari keskmiseks jäänud paar kargab aga keskel teiste paaride vahel.) 


\section{Kaerajaanist edasi}

Kaerajaani motiivianalüüsist, eriti selle viiendast väitest selgub taas, et luukerest pole mõtet kaua rääkida ümbritsevate lihasteta. Tuletame meelde veel kord Martini ja Pesovári eespool tsiteeritud (esimese jaotuse teine ja kolmas alajaotus) mõttekäiku keele- ja tantsuteaduse uurimismeetodite paralleelsuse kohta. Sellest järeldub, et tantsu(alatüüpi)de motiivivara lahkamine motiivideks, motiiviosadeks ja liigutuselementideks peaks kindlasti eelnema suurtele sünteesikatsetele. Teisisõnu, lähenedes tantsule struktuuri poolt, terviku vettpidavaks võrdlemiseks teiste tantsudega, on vaja hästi tunda tema koostisosi. Kui motiivianalüüs valmis, võime alustada kaardistamist. ${ }^{28}$

Kui mitu motiivi korraga luubi alla võtta, sõltub mitmest asjaolust. Lennates chomskyliku idealismiga võiks väita, et terve suure tantsudialekti (nt Fennoskandia) teatud tantsukihi motiivivara on võimalik märkida ühele kaardile ja niimoodi illustreerida hiiglasliku areaali kõigi esinevate tantsude motiiviseoseid. Kuid et vältida kaootiliste kaartide tekkimist, tuleb neid piiritleda mitte ainult ajas, vaid ka areaalselt ja tüpoloogiliselt. Kui väiksema areaali kaardid on ilusti koos, võime vaadata kaugemale ja hakata võrdlema teiste areaalide kaarte enda omadega.

Oma kaardile viisin ainult kaheksas kontratantsus ja nende variantides esinevad põhimotiivid, ${ }^{29}$ ja katsusin leida võimalikult lihtsad ja informeerivad nimed põhimotiivideks Kristjan Toropi sõnastiku baasil (Torop 2008). Korpuse kõik tantsud pole paratamatult samal tasandil. Kaerajaanil ja kupparimuoril on väga palju variante, need on kindlasti põhitüübi "kontratants" alatüübid, kuid mustlasepolka, pirupolka ja siisik on rohkem üksiktantsud. Kalamees, kuo tu tetsu ja ehk veel kolmõgeski kaarassimgi on oma variandirohkuse poolest rohkem alatüübid kui üksiktantsud, või vastandades kaerajaani ja kupparimuoriga pigem ala-alatüübid. Motiivikaardi üheks eeliseks ongi see, et kõigepealt paneme andmed (motiivid) peale, ja tantse sümboliseerivad isoglossid ilmnevad alles siis. Täpselt nagu keelekaardi puhul. Niisiis pole premisse, milline on kaerajaan, ja milline on kupparimuori, vaid andmed, mis määravad isoglosse, otsustavad selle üle ise. Tantsuisoglossid on seega kindlasti objektiivsemad kui traditsioonilised tõekspidamised. Kui näiteks motiivikaardi isoglossid näitaksid sootuks teist pilti kui oodatud, peaksime tantsude senist liigendamist vajalikul määral muutma ja mõned tantsud ehk isegi ümber nimetama.

Asendite vaatenurgast pakub kaart samuti huvi, sest kadrilli põhiasendist paaristantsuni liigitab ta isoglossidega saadud tantse ja tantsualatüüpe. Punktiirjoonega on märgitud päriskadrilliasendis tantsitud tantsu isogloss, pidevjoonega aga paaristantsu oma. Üleminekutüübi märkimiseks on kasutatud katkendjoont, ja neid on ka kahte sorti, rohkem punkteeritud katkendjoonega 


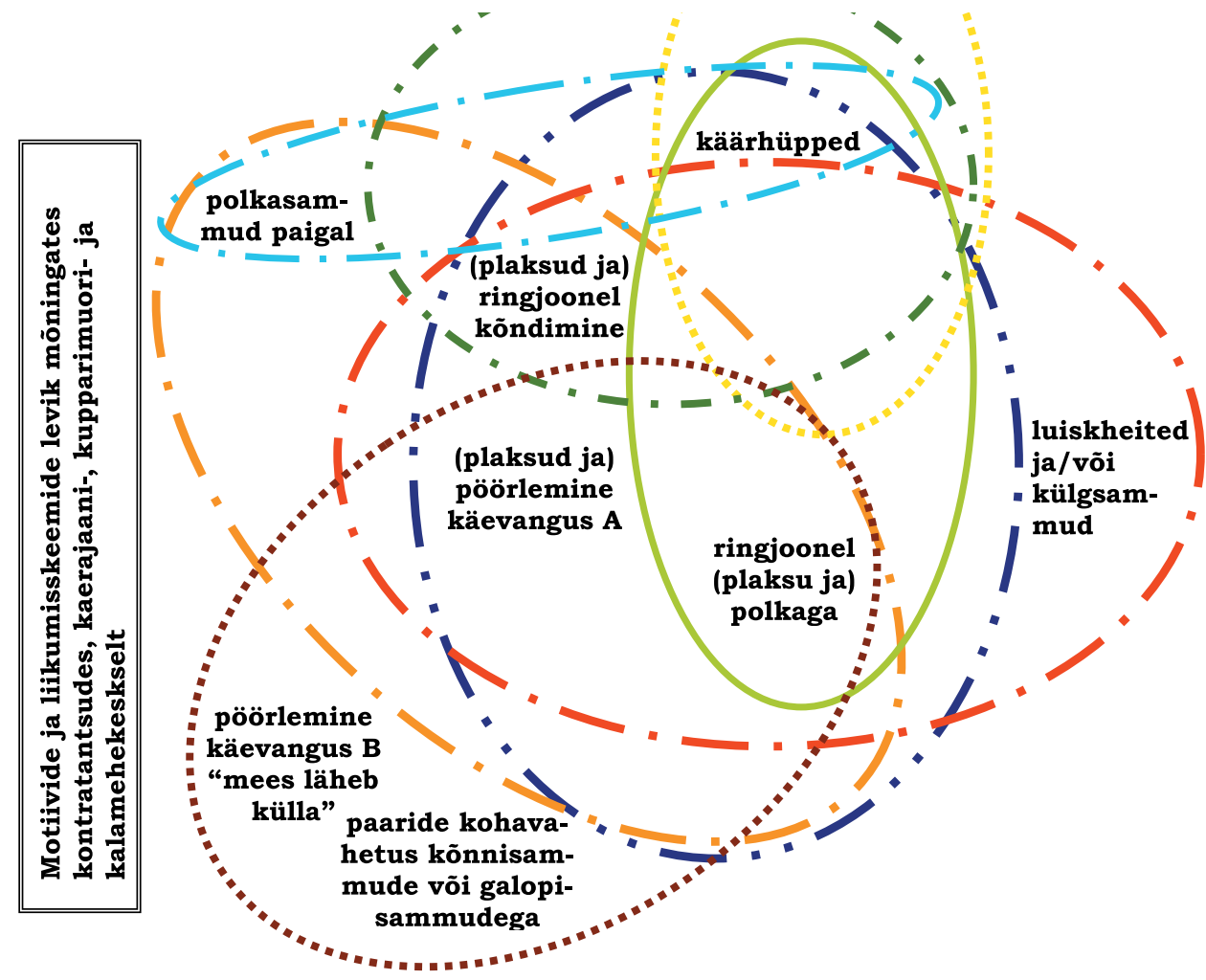

Märkide seletus

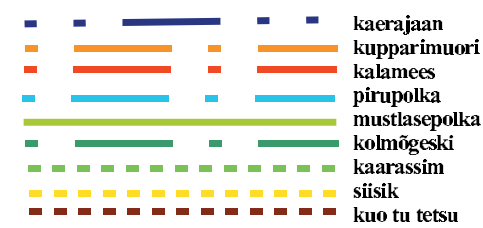

Joonis 4. Motiivide ja liikumisskeemide levik mõningates kontratantsudes kaerajaani-, kupparimuori- ja kalamehe-keskselt. ${ }^{30}$ Illustratsiooni saab värviliselt vaadata ajakirja sisekaanel.

näiteks illustreerime, et kaerajaanid on kadrillidele palju lähemal kui kupparimuorid (vähem punkteeritud katkendjoon), vaatamata sellele, et kahe alatüübi motiivivara on üllatavalt sarnane.

Motiivikaardis peitub veelgi võimalusi, aga mulle oli oluline näidata, et tantsutüpoloogilis-strukturaalne lähenemisviis on eesti tantsude uurimisel perspektiivne. Võib-olla oleks Kristjan Toropki pöördunud sellise struktuurianalüüsi poole kui ta oleks elanud kauem. Uuemad teed on teaduses alati põnevad, ja ma loodan, et kaerajaanide näitel lühidalt esitatud uurimissuund väärib eesti tantsufiloloogias tähelepanu ka tulevikus. 


\section{Kommentaarid}

1 Autor tänab Angela Arrastet ja Kalev Järvelat põnevate kontratantsutundide eest rahvatantsujuhtide koolis Tallinnas. Käesolev töö hakkaski idanema tantsujuhtide kooli kodutööst paar aastat tagasi. Samuti suur tänu õpetaja Ilma Adamsonile armsa kirja eest, millega aitas mul kindlusele jõuda tähtsas kaerajaani üksikasjas. Olen tänulik ka oma rahvatantsurühma Hõissassaa tantsijaile ja muusikuile, ka oma eesti-läti Kaerajaani - Cūkas Grīḳose lavale viimise eest. Tänan ka Eesti Kultuurkapitali ja soome-ugri rahvaste maailmakongressi Ungari rahvuskomitee esinaist, Éva Rubovszkyt, mitme Hõissassaaga seotud tantsualase toetuse eest.

${ }^{2}$ Erinevalt õigekirjutusreeglitest kirjutan Kaerajaani suure algustähega konkreetse tantsu puhul ja väikese algustähega tantsutüübi puhul, et alati oleks selge, kummaga on parajasti tegu.

3 Hiiuvalsivõte: poiss, hoides tüdruku paremat kätt oma vasakus käes, toetab selle oma seljale, ja hoides tüdruku vasakut kätt oma paremas käes, toetab selle tüdruku seljale. Võtte juures ollakse rinnutsi, puusade kohalt aga teineteisest tublisti kaugemal (Torop 2007: 31). Ülakeha on seega tugevasti ette kallutatud.

${ }^{4}$ Hele-Mare Kõmmus rääkis sellest 2006/2007. aasta tantsujuhtide kooli viimasel seminaril 2007. aasta novembris Kärdlas.

${ }^{5}$ Mis "liiderdamisse" puutub, ei toetanud ka luterlik kirik 19. sajandil maarahva tantsimist. (Pastor Hurt oli laia silmaringiga ja väga selgete põhimõtetega koguja ning kogumise organiseerija, aga kui vähe on ta tegelnud tantsukogumisega! Fakt on ka see, et isegi tänapäeval esineb mitmes kristlikus kirikus tantsuvastasust, kuid on raske öelda, kas hiiuvalsivõtte väljakujunemise tingisid tõesti usulahkude tantsukeelud. Selles küsimuses ei saa vist selgusele ilma kaugeleulatuva, tervet Fennoskandiat puudutava tantsuajaloolise analüüsita. Kui üldse. Sest ühelt poolt on küsitav, kas selline võte on vähem "häbematu" või hoopiski intiimsem, sest kehakontakti vorm on harjumatu, eriline. Tõsi küll, hiiuvalsivõte tähendab tantsijale selles mõttes sundasendit, et ta ei saa vabalt pöörata pead soovitud magusasse suunda, st ei mingit piilumist paarilise poole, rääkimata võimalikest sümboolsetest musidest. Samas on paariliste näod üksteisele väga lähedal, mis lisab võttele jälle intiimsust.

${ }^{6}$ Kahjuks pole andmeid, kuidas täpselt hiidlased tantsimas käisid, teadusliku tantsukogumise ajaks olid need rahvarõivad igapäevaelust valdavalt kadunud. Kui just rahvarõivateadlased (Igor Tõnurist, Reet Piiri jt) ei oska selle kohta midagi täpsemat öelda.

${ }^{7}$ Kui pöörlemine oli kombineeritud tüdruku tõstmisega, ei tohtinud puusad olla (peaaegu) koos, nagu paljudes uuemates paaristantsudes, sest parimal juhulgi oleksid nõelakoda ja noatupp paarilisi seganud.

${ }^{8}$ Niisugust liigendamiskatset näeme eesti tantsuteaduseski varakult: Tampere ja Põlmäe valimikus on tüübilt sarnased tantsud grupeeritud, kadrillid nt ühte rühma, Kaerajaanile järgnevad käärhüpetega tantsud nelinurkasendis või paaris, nagu kaaratsimm, mustlasepolka ja pirupolka. Ainult käärhüppetega siisik pole kaerajaani naabriks, tema on oma nelja paariga nelinurkasendi tõttu "päriskadrillide" hulgas.

9 Kusjuures keel on mõistagi verbaalne kood, tants aga mitteverbaalne.

${ }^{10}$ Bartóki klassifitseerimispõhimõtete aluseks oli Krohn, Ilmari: Welche ist die beste Methode, um Volks- und volksmässige Lieder nach ihrer melodischen (nicht textlichen) 
Beschaffenheit lexikalisch zu ordnen [Mis on parim viis rahvalaulude leksikaalseks korraldamiseks nende meloodiliste (mitte tekstiliste) omaduste alusel (Sammelbände 1902-1903: 643-660).

${ }^{11}$ Käesoleva artikli autor vaatab lähemalt Martini ja Pesovári pakutud keele- ja tantsustruktuuri analoogiaid. Omaette ja kiiduväärt ettevõte oleks, kui keegi vastandaks rahvatantsudele strukturaalselt ka teised folkloorižanrid.

12 Martin ja Pesovár pühendasid tantsumotiividele palju teoreetilisi ja rakenduslikke töid 1950ndatest aastatest 1980ndateni (Martini varase surmani). Motiivi struktuuritasandil eristasid nad peale motiivi ja motiiviosa ka liht- ja liitmotiivi jms ühelt poolt peensustesse mineva struktuurilise analüüsi tõttu, teiselt poolt aga ajaloolis-võrdleva lähenemise pärast. Viimase järgi on kõrgelt struktureeritud motiivirohke tants nähtavasti "arenenum" kui motiivivara poolest vaesem või mitteanalüüsitav tants. Jämeda võrdlusega on küsimus selles, kas Pikk ingliska on nt siisikust arenenum või mingil põhjusel lihtsalt teistsugune. Käesolevas töös ma ei puuduta seda problemaatikat, kuid minust on väga kaugel igasugune puhtevolutsionistlik lähenemine kultuuriliste nähtuste analüüsimisel. Sellest probleemist annab kriitilise ülevaate Könczei 1994. Tema arvates pole meil mingit alust eeldada, et tants areneb morfoloogilis-süntaktilises mõttes lineaarselt mingisugusele reeglipärasusele alludes, ja seega tema struktuuriline korrapärasus või korrapäratus oleks teatud tantsuajaloojärgu tunnusmärk [Semmi okunk sincs azonban azt feltételezni, hogy a tánc valamilyen belső törvényszerüségnek engedve lineáris szintaktikai és morfológiai fejlődésen megy keresztül, és ezáltal strukturális rendezettsége, vagy lazasága egy történeti korra utal] (Könczei 1994).

${ }^{13}$ Katsusin kõik õppesõnad kohandada eesti tantsude strukturaalseks analüüsiks.

${ }^{14}$ Vabad morfeemid võivad erinevalt afikseist esineda lauseis iseseisvalt.

15 Teatud kontratantsumotiivid on Euroopas laialt levinud kuni Uuraliteni. Käesolevas uurimuses mainin sarnaseid tantse Soome-Karjalast ja Lätist, kuid see ei tähenda, et mujal siin analüüsitud eesti tantsudega sarnaseid pole. Eri kontratantsutüüpide leviku uurimine Põhja- ja Ida-Euroopas ei mahu käesoleva uurimuse raamidesse, see polnud ka eesmärgiks.

${ }^{16}$ Tervitamist kasutan tantsupraktikast võetult kontratantsumotiivi nimena mina. Torop 1995: 115 selgitab motiivi tantsukirjelduses järgmiselt: peapaarid lähevad kolme sammu ja lõppsammuga teineteise vastu ning taganevad samamoodi oma kohale tagasi. Külgpaarid kordavad peapaaride tegevust.

17 Tantsu sappu Säkkijärveltä kõik motiivid sooritatakse madalhüpaksammudega (matala hyppyaskelikko) v.a ruusu, mida võib tantsida ka kõnnisammudega (vrd Tanhuvakka 1977: 254).

18 Tantsuvalemid pole siiski analoogsed Labani kinetograafiaga, selle põhimõtteist kokkuvõtlikult vaata Eda Pomozi 2005: 122-130. Viimane on võimalikult täpne tantsukiri, eelmine lihtne struktuurianalüüs, kuid abstraktsiooni kõrge tase iseloomustab mõlemat.

${ }^{19}$ György Martini tsiteeritud mõtteterad pärinevad loomulikult palju varasemast ajast, need arusaamad ja mõtted kujunesid tal 1950ndate aastate suurtest kogumisretkedest saadik kuni tantsumonograafiates kristalliseerumiseni. Ise kasutasin tsiteerimiseks postuumset teost Martin 1995.

${ }^{20}$ Murdegeograafia ei tegele murrete ajalooliste muutuste kirjeldamisega, ent Martini elutöös oli ajalooline aspekt keskne. Nii tüpoloogilise kui ka geograafilise lähenemise puhul tegi ta ajaloolis-kronoloogilisi järeldusi tantsu eri arengufaase iseloomustavate struktuuriliste omaduste ja nende leviku kohta. 
${ }^{21}$ Kui palju on "võimalikult palju", seda täpselt ei tea. Igatahes vaatasin läbi palju skaneeritud käsikirjalisi Toropi materjale (võimaluse eest siiras tänu Angela Arrastele), aga kontratantsude kohta ei leidnud esialgu märkimisväärset uut. Siiski tekib küsimus, kas ja kui palju on veel trükis avaldamata Toropi tantsukirjeldusi. Igatahes oleks nii tantsujuhtidele kui ka folkloristidele äärmiselt kiiduväärt, kui peagi toimetataks trükki Toropi allesjäänud käsikirjalised materjalid.

${ }^{22}$ Ühe tsüklilisuse poolestki huvitava tantsu, vengerka teest kirjutab Eda Pomozi oma bakalaureusetöös ja lühemalt ka ühes uurimuses (Pomozi 2005: 131-132).

${ }^{23}$ Populaarseimaid oli Ungari Kuningriigi reformiajastul (1825-1848) ballitants "Körtáncz". Ernő Pesovár tõi selle refolkloriseerumise kohta äärmiselt põnevaid näiteid (vrd nt Pesovár 2003 ja vt veel Eda Pomozi bakalaureusetöö vastavat peatükki, Pomozi 2007:64-70).

${ }^{24}$ Kontratantsuramatu kaerajaanid pärinevad eranditult ERA materjalist. Veel üks mõte selle kohta, kui palju on avaldamata kontratantse Toropi käsikirjalises materjalis. Kui oli, miks ta ise neid oma raamatusse ei pannud...

${ }^{25}$ Sellisel puhul ei pidanud tants kohalikus tantsupärimuses sassi minema, vaid oletatati, et informant ei mäletanud enam päris täpselt.

${ }^{26}$ Läti Cūkas Grīksoses on tänapäeval valdavalt vastupidi, ja lätlane ei liigugi enam päikese, vaid hoopis kellaosuti järgi, nagu ka mujal paljudes maades. Soomlased kasutavad veel ilusaid tantsusõnu vastapäivään/myötäpäivään, Anna Raudkats võttiski need väljendid eesti tantsusõnavarasse just sealt, ja tema kasutaski sõnu vastupäeva/möödapäeva. Isoglossiks läti ja eesti kaerajaanide vahel on mõistagi erinev liikumisskeem, olenemata terminoloogiaerinevustest. Selle tõttu on lätlastel täiesti tavaline ka parema jalaga alustamine.

${ }^{27}$ Toomi avaldas kaerajaani esmaselt oma suures rahvatantsuraamatus aastal 1953. Toomi 1947. aasta tunduvalt õhemasse valimikku kaerajaan ei mahtunud. Ka Toomi memuaaridest Kaerajaanist tantsupeoni ei leia selle muutuse kohta juhtnööri, ta ei pidanud ilmselt oluliseks "pisiasja" tekkimislugu trükis avaldada. (Pisimuutus oli tehtud nii osavalt, et tänapäeval on valdav osa tantsivatest eestlastest veendunud, et tantsu B osas $2+3$ plaksu ja pärast nelja sammuga ringjoonel kõndimine on kaerajaani iidne folkloorne motiiv. Selline muutus pidi tegelikult tulema tantsu "õilistamise" pärast (kui laenata Toomi sõna). Toomi otsene õpilane, koreograaftantsujuht Ilma Adamson kirjutas mulle selle kohta nõnda:

Toomi oli see pedagoog, kes rõhutas alati liikumiste harmooniat. Ta viis tantsu lavale, täpsustas tantse ja põhisamme. Nii oli ka Kaera-Jaaniga, kuna ta oli muusik, võis teda mõjutada B-osa 2. takti tegevus muusikaliselt, mis tingis seda kolme plaksu [kolm plaksu siis muusika kümnendal taktil, peale üheksandas taktis esinevat kaks käteplaksu - P. P.] ning ta leidis, et tantsijad jõuavad kohad vahetada nelja sammuga ja mitte kuuega. Nii ta viiski selle sisse ka oma "Piiblisse" ja hiljem on seda ka nii tantsitud, sest oli Toomi raamat aabitsaks kõigile, ka väliseestlastele (kiri autorile 21.01.2009).

${ }^{28}$ Relevantseid motiive ja tantsuisoglosse võimepaigutada ka geograafilisele või kihelkonnakaardile täpselt nagu murdekaartide puhul. Selline kaart tuleks kindlasti suur ja palju keerulisem kui selles uurimuses esitatav motiivivarakaart, kuid see sisaldaks detailset informatsiooni mitte üksnes isoglosside (tantsude) ja nende motiivide kohta, vaid ka nende täpse leviku kohta, seega lubaksid sellised kaardid teha areaalseid ja tantsuloolisi järeldusi.

${ }^{29}$ Kolme variantiderohke tantsu (alatüübi), kaerajaani, kupparimuori ja kalamehe puhul ei võtnud ma arvesse teisi motiive kui oma analüüsi põhikorpuses (Torop 
1995) leiduvaid. Kuo tu tetsu puhul tegin natuke teistiti, et saada reaalsemat üldpilti.

30 Motiivikart on kaerajaani-, kupparimuori- ja kalamehe-keskne, sest kaerajaani isoglossiga arvestades toon sisse kõigepealt selliseid tantse, mille isoglossid moodustavad kaerajaani omaga kimpe. Need on motiivivara sarnasuse tõttu kõigepealt kupparimuori ja mõned vähem varieerunud paaristantsud. Mustlasepolka on näiteks täiesti kaerajaani-sisene, koosnedes viimase põhimotiivist ja polkast. Selle kaardi peal on muidugi ainult võimaliku eesti kontratantsu-motiivivara võrgustiku murdeosa, nii paistab kaardil kalamehe luiskheide või kuo tu tetsu "pöörlemine käevangus B: mees läheb küla peale" olevat üksikmotiiv, kuid need motiivid esinevad jälle teistes tantsudes, viimane nt Karjala-Soome tantsus sappu Viipurista (Tanhuvakka: 256-257). Kalamehe-kesksus tähendab ainult, et selle tantsu puhul näitame, kuidas võiks võrgustikku edasi punuda. Võrgustik on jätkatav peaaegu lõpmatuseni, seda sümboliseerivad kaardi ülemise serva lahtised ellipsid (kolmõgeski kaarassimi ja siisiku omad).

\section{Allikad}

Ilma Adamsoni kiri autorile 21.01.2009.

\section{Kirjandus}

Bartók, Béla 1924. A magyar népdal. Budapest.

Kermik, Heino 1983. Ullo Toomi - kaerajaanist tantsupeoni. Tallinn: Eesti Raamat.

Könczei, Csilla 1994. A nem-verbális rítusok verbális értelmezhetóségéröl / On the verbal representation of non-verbal rytes. Doktoriväitekirja peatükk. Kolozsvár. (http:// konczei.adatbank.transindex.ro/belso.php? $\mathrm{k}=34 \& \mathrm{p}=3128$ - 24. märts 2009.)

Martin, György 1995. Magyar tánctípusok és táncdialektusok. 2. átdolg. kiad. Budapest: Planétás Kiadó.

Martin, György \& Pesovár, Ernő 1960. A magyar néptánc szerkezeti elemzése. Dienes, Gedeon \& Morvay Péter (toim). Tánctudományi Tanulmányok 1959-1960. Budapest, lk 211-248.

Martin, György \& Pesovár, Ernő 1964. A motívumtípus meghatározása a táncfolklórban. Dienes, Gedeon (toim). Tánctudományi Tanulmányok. 1963-1964. Budapest, lk 193-233.

Pesovár Ernö 2003. A magyar néptánc története. Szombathely: Berzsenyi Dániel Főiskola.

Pomozi, Eda 2005. Labani kinetograafiast eesti rahvapäraste tantsude kogumisel ja uurimisel. Hiiemäe, Mall \& Labi, Kanni (toim). Aega otsimas. Pro Folkloristica XII. Tartu, Eesti Kirjandusmuuseum, lk 120-138.

Pomozi, Eda 2007. Rahvuslike seltskonnatantsude teke ühe maa näitel. Bakalaureusetöö peatükk. Tartu.

Pomozi, Péter 2008. Hej Zabjancsi, Zabjancsi... Írások Havas Ferenc hatvanadik születésnapjára (CD-raamat). Budapest: ELTE, lk 627-640. 
Põldmäe, Rudolf \& Tampere, Herbert 1938. Valimik eesti rahvatantse. Tartu: Eesti Rahvaluule Arhiivi Kirjastus.

Raudkats, Anna 1926. Eesti rahvatantsud. Tartu: Postimees

Sammelbände 1902-1903 = Sammelbände der Internationalen Musikgesellschaft IV. Leipzig: Breitkopf \& Härtel, lk 643-660.

Tampere, Herbert 1975. Eesti rahvapillid ja rahvatantsud. Tallinn: Eesti Raamat.

Tanhuvakka 1977 = Pirkko-Liisa \& Esko Rausmaa (toim). Tanhuvakka: suuri suomalainen kansantanssikirja. Porvoo: WSOY.

Toomi, Ullo 1947. Valimik eesti rahvatantse. Rahvaloomingu Keskmaja toimetis. Tallinn: Ilukirjandus ja Kunst.

Toomi, Ullo 1953. Eesti rahvatantsud. Tallinn: Eesti Riiklik Kirjastus.

Torop, Kristjan 1995. Kontratantsud. Tallinn: Rahvakultuuri Arendus- ja Koolituskeskus \& Eesti Keele Instituut.

Torop, Kristjan 2008. Eesti rahvatantsu oskussõnastik. 4. trükk. Tallinn: Rahvakultuuri Arendus- ja Koolituskeskus.

\title{
Summary
}

\section{On Estonian Kaerajaan Dances and Typology of Dance}

\author{
Peter Pomozi
}

Key words: dance types, dance typology, Kaerajaan, motifs

According to a very old theory, the research methods of dialectology and language typology are also applicable in the study of folk dances. Studies into dance typology form a significant part of the work of Hungarian dance historians György Martin and Ernő Pesovár (e.g., Martin-Pesovár 1960, 1964, Martin 1995). Author of this study introduces the basic principles of the structural analysis methods of Martin and Pesovár, and at the same time compares the common parameters of dance structures and linguistic structures. Structural analysis is used to demonstrate this on one of the most popular Estonian contra dances, the Kaerajaan dance.

The Kaerajaan dances are primarily examined in the light of the book Kontratantsud ('Contra Dances', 1995) by Kristjan Torop. The entire second chapter is dedicated to this analysis. The third chapter presents possibly the most detailed analysis of Kaerajaan dances, in which the parts of the dance is divided into motifs and similar motifs are systematized in groups. The last part of the article takes a look further: the author examines the relations of a few types of contra dance, and the frequency and distribution of the motifs, introducing a new type of'dance isogloss'. This model provides a solid foundation for showing how this particular topic may help us in the research of both spatial and temporal aspects of the corresponding Fenno-Scandinavian folk dances. 